This item was submitted to Loughborough's Research Repository by the author.

Items in Figshare are protected by copyright, with all rights reserved, unless otherwise indicated.

\title{
Talent identification and development in elite youth disability sport
}

\section{PLEASE CITE THE PUBLISHED VERSION}

http://dx.doi.org/10.1080/17430437.2015.1124566

\section{PUBLISHER}

(c) Taylor \& Francis

\section{VERSION}

AM (Accepted Manuscript)

\section{PUBLISHER STATEMENT}

This work is made available according to the conditions of the Creative Commons Attribution-NonCommercialNoDerivatives 4.0 International (CC BY-NC-ND 4.0) licence. Full details of this licence are available at: https://creativecommons.org/licenses/by-nc-nd/4.0/

\section{LICENCE}

CC BY-NC-ND 4.0

\section{REPOSITORY RECORD}

Houlihan, Barrie, and Pippa Chapman. 2019. "Talent Identification and Development in Elite Youth Disability Sport”. figshare. https://hdl.handle.net/2134/20374. 
Talent identification and development in elite youth disability sport

\title{
Barrie Houlihan and Pippa Chapman
}

\author{
Corresponding author: \\ Professor Barrie Houlihan \\ School of Sport, Exercise \& Health Sciences \\ Loughborough University \\ Loughborough, LE11 3TU \\ (T) $++(0) 1509226364$ \\ (E) b.m.j.houlihan@lboro.ac.uk
}




\section{Talent identification and development in elite youth disability sport}

Two of the most significant developments in elite sport in the last thirty years have been the increasing profile of youth sport and of disability sport. While some sports, such as rowing and golf, have had junior world championships since the late 1960s it is in the last thirty or so years that the growth in international elite events aimed at juniors/youth has been most rapid. FIFA, the world federation for football, held the first under 16 World Cup in 1985, the International Triathlon Union began organising events for juniors who can be as young as 14, in the late 1990s and the FINA, the international federation for swimming, held the first world junior swimming championships (girls 14-17 and boys 15-18) in 2006. The increase in the number of single sport competitions has been complemented by a similar expansion in the number of international multi-sport youth events such as the Maccabi Youth Games (first held in 1982), the Commonwealth Youth Games (2000), the Australian Youth Olympic Festival for 13-19 year olds (2001) and the Youth Olympic Games (2010).

While much of the recent increase in the number of international sports events has been driven by the demand from the media for more sports products to broadcast this is unlikely to be a significant explanation in relation to youth sports competitions as there is little evidence of interest in youth events, even the Youth Olympic Games, among broadcasters. More likely explanations include the value that national sport organisations see in providing high quality competition opportunities for the members of their youth squads as part of their athlete development programmes (Skille and Houlihan 2014). Youth elite international competitions are especially valued in early peak sports such as gymnastics in order to avoid a situation where the senior Olympic Games is the first high pressure mass audience competition for the young athlete Skille and Houlihan 2014). A further explanation is the emphasis given in many sports to early specialisation which is in part an acceptance of the theory of Simon and Chase (1973) that a minimum of ten years application is needed to attain expertise which was endorsed by subsequent studies of sports as diverse as figure skating (Starkes et al. 1996), middle distance running (Young and Selmela 2002), football (Helsen 2000) and netball, basketball and field hockey (Baker and Cote 2003, see also Baker and Young 2014 for an overview). A final partial explanation 
might also be that clubs and their national federations assume that early involvement in high level competition is a way of ensuring the commitment of talented young athletes to a particular sport.

Although one of the earliest examples of elite disability international sports events, the Deaflympics, dates from 1924 most examples are much more recent with the first Paralympic Games held in 1960 and the first Special Olympics, for people with an intellectual disability, dating from 1968. It is even more recently that elite disability sport has reached a global media audience. It was not until 1976 that the Paralympic Games received television coverage in the form of recorded highlights. Even as recently as the 1996 Games broadcasting was only possible because the Games organisers agreed to pay the broadcast companies (Cashman and Darcy 2008). Although the 2012 Paralympic Games were broadcast to 113 countries and achieved a cumulative audience of 3.4billion television coverage of elite disability sport beyond the summer Paralympics is extremely limited. The growth in profile of elite disability multi-sport events may arguably be less the result of demand from the media for products, but more the result of: sustained activism by not for profit organisations, such as the International Sport Organisation for the Disabled (IOSD) in the 1960s; the agency of an entrepreneurial few, including Ludwig Guttmann, founder of the Stoke Mandeville Games, and Sir Philip Craven, current President of the linternational Paralympic Committee: and the by-product of disability (and broader civil) rights campaigns mainly in western countries, such as the UK, Canada and the United States (see Campbell \& Oliver 2013, 2009, Vaughn-Switzer 2003). However, the growth in profile of the Paralympic Games has certainly contributed to the increase in the number of world championship competitions for individual sports although many are organised by the International Paralympic Committee (IPC) rather than by the Olympic or Paralympic international federations. The IPC organised the first world swimming championships for athletes with a disability in 1994 in Malta and the first athletics world championships in the same year in Berlin while the International Triathlon Union organised the first Paratriathlon events in the late 1990s.

It is the combination of the increasing number of youth elite sport competitions on the one hand and the growth in elite level disability sports competitions and the increase 
in media interest in the Paralympic Games on the other that provides the context for this paper. Although the volume of published research into elite youth sport is modest by comparison to that on adult elite sport it is still significantly larger than that which focuses on disability elite youth sport. The aim of this paper is to examine elite youth disability talent identification and development (TID) in three sports (wheelchair basketball, disability tennis and boccia) in the United Kingdom and to assess the evidence for convergence between disability sport talent identification and development systems. Particular attention is paid to: a) the process of talent identification in three sports; b) the role of national organisations in shaping the priorities of the system; c) the processes in place to protect the welfare of young elite disabled athletes; and d) the prospects for the future development of elite youth disability sport.

\section{Theoretical context}

The literature on disability sport has grown substantially in recent years with much of it being informed by wider theoretical debates around the changing narratives of disability. The medical and individualised narrative conceptualised 'disability as an impairment owned by an individual' (Thomas 2008: 206) and implied a need for professional intervention and resulted in the objectification of the individual. The challenge to this individualised medical model of disability grew steadily from the 1980s with campaigners such as Oliver (1983, 2013; see also Oliver and Barnes 2012) arguing that the focus should be on the ways in which the structure and organisation of society created barriers to the full participation of disabled people. The increased acceptance of the social model of disability fuelled activism and academic interest in access to sports opportunities by people with disabilities. The stimulus to academic interest led to research across a wide range of aspects of the interconnection between disability and sport including the perceptions and selfperceptions of the disabled athlete (Smith 2013, Howe 2008, Silva and Howe 2012 , Purdue and Howe 2012), social inclusion of people with disabilities in sport (Thomas and Smith 2008, Sport and Recreation Alliance 2013, Siperstein et al 2009, Liu 2009), the history of the Paralympic Games (Legg and Steadward 2011, Gold and Gold 2007), and the inclusion of young disabled people in sport (Finch 2001, 
Fitzgerald 2009). Where the literature is more scant is in the area of disabled youth talent identification and how that talent is developed to elite competitive level.

The paucity of research in the area of disabled youth talent identification is in marked contrast to the extensive literature on talent identification and development in mainstream sport. In the mid 1990s Clumpner (1994) noted the importance of sustained financial support for athletes, well-funded training centres, concentration on a selection of sports and the development of a pool of athletic talent. Despite some scepticism about the possibility of identifying the properties of an effective TID system research gathered momentum with Oakley and Green (2001) providing what many considered to be, at the time, the most persuasive analysis identifying ten characteristics of successful elite systems. Green and Houlihan (2005) developed this initial analysis and identified specialist facility development, sport science and medicine services, a competition structure focused on preparation for major sport competitions such as the Olympic Games, high quality coaching and well-funded athletes as integral to success at the highest levels. This research was futher developed and refined by the extensive SPLISS (Sports Policy Factors Leading to International Sporting Success) research programme (De Bosscher et al 2008, 2009a, 2009b.

One significant feature of the current research into elite sport systems is the identification of evidence of a growing convergence across countries and sports, particularly Olympic sports, most notably in relation to: talent identification; investment in coaching and sports science; funding to enable athletes to train full time; and the design of competition frameworks to support Olympic ambitions (De Bosscher et al. 2009a, 2009b, Houlihan and Green 2008, Bergsgard et al 2007). The identification of convergence has tended to focus on the development of similar practices (in relation to funding, training and domestic competition structures for example). While the emergence of common practices is important there is a broader range of dimensions of convergence which may be assessed and which are relevant to an understanding of the recent history of elite youth disability sport. Houlihan (2012) identified seven dimensions of convergence. Table 1 describes the different dimensions and indicates their relevance to talent identification and development in elite youth disability sport. 


\section{Table 1 about here}

The range of dimensions of convergence identified in Table 1 draws attention to the processes that led to the pattern and degree of convergence observed. For example, one explanation for convergence emphasises policy learning and transfer between sports and countries prompted in part, as is often the case, by a high degree of uncertainty about how to produce medal success and by a high degree of risk aversion due to the threat of withdrawal of public funding or sponsorship (Rose 2005). The extent of resource dependence on government of many Olympic and non-Olympic NGBs is extensive and makes it difficult for them to determine an independent policy path, even assuming that they should wish to do so. However, the extent of resource dependence is far greater among disability sport organisations whether they are NGBs such as the GB Wheelchair Basketball Association (GBWBA) and Boccia England dependent on funding from government and charities or whether they are an integral part of a mainstream NGB such as is the case for disability swimming which relies on funding from the mainstream NGB and government agencies. It would indeed be surprising if these patterns of resource dependence did not reinforce isomorphic tendencies.

One of the problems of assessing the extent of convergence is deciding what significance to attach to the seven dimensions identified in Table 1. For example convergence on 'agendas and aspirations' may simply indicate a superficial commitment to a particular policy objective whereas if convergence in 'agendas and aspirations' is underpinned by convergence in relation to the allocation of inputs then the degree of convergence may be more significant. Similarly, evidence of convergence in relation to 'discourse, ideology, values' should be deemed more significant than convergence in relation to 'implementation' and the selection of delivery mechanisms. Hall (1986) offers a useful typology which not only provides a foundation for the analysis of the nature and extent of convergence and the effect of isomorphism, but which also indicates the relative significance of different aspects of convergence. The typology has been widely adopted not only in discussions of theories of policy change (for example Origins 2000, Lascoumes \& Le Gales 2007) but also in analyses of policy change in a wide range of different policy sub-sectors 
such as social welfare (Béland 2005), European Union policy-making (Radaelli 2003), gender and welfare (Lewis 2002), environment (Jordan et al 2003) and tourism (CM Hall 2011), Hall specifies three 'orders' of policy change the first of which refers to alterations to the intensity or scale of an existing policy instrument, such as an increase in an existing funding stream for elite youth disability sport development. Second order changes are those that introduce new policy instruments designed to achieve existing policy objectives: examples of which would include the introduction of talent transfer schemes. Finally, third order changes are those that involve a change in policy goals and would include the decision by disability sport organisations to adopt an elite development strategy where previously the policy priority had been on participation and social inclusion. Third order changes relate most closely to the dimensions of 'agendas and aspirations' and 'contextualising discourse/ideology/values' identified in Table 1. Second order changes relate to the dimension of 'implementation' while first order changes correspond to the 'inputs' dimension. Combining Hall's typology with the dimensions of convergence provides a rich framework for the analysis of elite youth disability sport systems.

\section{Methodology}

Adopting a case study research design the primary method of data collection adopted for this study was a series of semi-structured interviews. A search for relevant documents such as annual reports and statements of aims and activities available on official websites was also conducted which provided contextual data, which informed the development of the interview schedule, rather than providing direct insight into processes of youth talent identification and development. The criteria for the selection of organisations from which interviewees would be sought were that the organisation had either a direct responsibility for talent identification and development in one of the selected sports or that they were a significant source of resources, such as finance or | expertise. Consequently, in addition to the lead organisations for the three sports (the Tennis Foundation, GB Wheelchair Basketball Association and Boccia England) interviews were also conducted with representatives from the Youth Sport Trust and the British Paralympic Association. The criteria for the selection of interviewees from fthe Tennis Foundation, GB Wheelchair Basketball Association and Boccia England 
were that they should have a direct role in, and senior responsibility for, the design and management of the elite youth development system within their organisations.

All three organisations were small by comparison to mainstream sport organisations. Consequently, the range of potential interviewees who met the criteria for selection was limited to a single interviewee. The criteria for the selection of interviewees from the Youth Sport Trust and the British Paralympic Association was that they had direct responsibility for funding and working in partnership with the NGBs to deliver their objectivesor providing advice to the NGBs. As with the three NGBs the number of potential interviewees who met the criteria of seniority (i.e. strategic responsibility) and direct involvement in disability sport development was limited to one member of the two organisations. A similar set of topics was covered in each of the five interviews which lasted between 40 and 75 minutes (a copy of the interview schedule used for the NGB interviews is provided in the Appendix $A$ ). All interviews, with one exception, were recorded and transcribed and subject to text-driven thematic analysis (Krippendorf 2013). Thematic analysis began with each researcher undertaking an initial reading of the transcripts and field notes and identifying major issues. The data were read a second time by each researcher independently in order to check on the identification of issues and to group the issues into clusters/emergent themes. The researchers then compared their results and checked on the assignment of issues to themes (May 1997, Strauss \& Corbin 1990, Riessman 2008).

\section{The particular context of youth disability sport}

One of the defining characteristics of contemporary youth disability sport in the UK is the recent increase in governmental interest in, and funding for, elite disability sport development. Paralympic World Class Performance Programme (WCPP) funding, which is distributed to the Paralympic NGBs, has increased from $£ 10 \mathrm{~m}$ for four year funding cycle up to the 2000 Sydney Games to $£ 29.5 \mathrm{~m}$ for the Beijing Games cycle to an estimated $£ 72.7 \mathrm{~m}$ for preparation for the 2016 Rio de Janeiro Games. A second significant characteristic is the organisational complexity of elite disability sport. In addition to the British Paralympic Association which is a direct equivalent to the British Olympic Association, there is also the English Federation of Disability 
Sport which is mainly concerned to promote participation, but has some responsibility for developing pathways to the elite level. In relation to the organisation of particular sports some disability sports have their own NGB (such as boccia and wheelchair basketball) while others are nested within the mainstream NGB (such as swimming and track and field). Finally, there are national organisations that are defined by type of disability, such as those for deaf athletes (UK Deaf Sports which prepares athletes for the Deaflympics) and blind athletes (British Blind Sport which supports athletes who take part in the International Blind Sport Federation World Games).

A third characteristic of the contemporary context of youth disability sport is the recent increase in social and political awareness of the need to establish guidelines to ensure protection of the interests of young athletes - whether disabled or not. In most respects the factors to be taken into consideration when examining elite youth sport development processes are the same whether one is referring to athletes with or without a disability. Young athletes are children whose interests need to be protected against infringement by adults - whether parents, coaches, sponsors or event organisers. One obvious reference document for assessing the extent to which child athletes are being harmed by or are benefitting from their experience of sport is the United Nations Convention on the Rights of the Child (CRC). Until the Convention children were most commonly recognised as passive subjects of domestic law (Veerman 1992). The Convention, signed by all but two UN members contains 54 articles many of which have a direct application to sport. For example, there are articles that refer to:

- the principle of the best interests of the child (Article 3)

- the right to have their views taken into account (Article 12)

- the protection from neglect and abuse and other forms of violence (Article 19)

- the right to rest, leisure, recreation and cultural activities (Article 31), and

- the right to be protected from economic exploitation (Article 32)

For David (2005) the CRC is a benchmark against which the treatment of young elite athletes can be assessed. However, he notes that while young elite athletes are 
potentially vulnerable to exploitation there is insufficient evidence to indicate whether 'children involved in competitive sports are as much, more or less vulnerable to abuse, neglect or violence than children who are not involved' (David 2008: 111). However, the examples of abuse, whether sexual (Brackenridge 2001) physical and psychological (Martens, 1978; Tofler, 1996; Ryan 1995, Brackenridge 2010) or economic (Donnelly 1997) though possibly rare are a source of concern because of the position of trust of the adults involved and the questions that they raise about the responsibilities of clubs, NGBs, governments and other stakeholders. The CRC applies with equal force to young disabled athletes and with greater intensity to young athletes with a learning disability, but is not the only benchmark for assessing the fair treatment of young disabled elite athletes. The UN Convention on the Rights of Persons with Disabilities, adopted in 2006, reinforces many of the articles of the $\mathrm{CRC}$, but specifically mentions a) that children with disabilities shall have equal rights with adults (Article 23); and b) 'Countries are to promote participation in cultural life, recreation, leisure and sport ... Countries are to ensure [disabled people's] participation in mainstream and disability-specific sports' (Article 30). At the domestic UK level the 1996 Disability Discrimination Act (DDA) anticipated much of the content of the UN Convention although, like the Convention, the DDA has been criticised for being vague and lacking determined implementation (Thomas 2008).

Any assessment of elite youth sport systems, whether primarily focused on disabled athletes or not, needs to acknowledge the multiple motives of various stakeholders while also acknowledging the imperative of ensuring that the creation of opportunities for young people is not subordinated to the political, organisational and economic motives of a rapidly expanding sports sector in a manner that is detrimental to the interests of the young athlete.

\section{Talent identification in disability sport}

\section{Wheelchair basketball}

Although schools can play a significant role in talent identification and development it is the network of voluntary run local clubs which provides the main focus for talent identification (TID). Schools are generally seen as important in promoting participation and in providing a pathway into club membership, but it is the club 
which nurtures talent. The GB Wheelchair Basketball Association (GBWBA) for example has a network of 'Change for Life' clubs which are school-based but they still rely primarily on clubs as too few schools provide sufficient opportunities for disabled athletes. Nevertheless the Association does make use of the School Games as a development opportunity. At levels 1 to 3 (local, county and regional) teams play an adapted version of the sport in which only one member of a team needs to be a disabled wheelchair user, but at level 4 (national level) the competition is organised by the NGB and athletes are selected from regional development squads. According to the interviewee at GBWBA 'the School Games provides a really important environment for players [as they are] surrounded by other talented people, good competition etc.. The experience is a key part of their development' (interview 17.11.14).

However, the GBWBA has one of the more elaborate networks of clubs which send athletes to regional competitions at which GB coaches scout for talent. If a talented athlete is identified they will be invited to join the national training academy at the University of Worcester. Although the Association has an under 15 squad the target age range of the Association is 16 to 22 years. The under 15 squad (and the under 19 squad) have been supported by a charity, the Lords Taverners, since 2007. The Association has developed a talent monitoring matrix which scores the different technical skills required (such as ball handling, chair pushing etc.) as well as lifestyle elements. Due to the range of technical and strategic skills being broad and their acquisition and refinement being a longer term slow-process the Association sees little potential value in investing in talent transfer schemes.

\section{Disability tennis}

In contrast to the GBWBA development activity in elite disability tennis is undertaken by a charity, the Tennis Foundation (TF), rather than by the sport's NGB. Although much of the activity of the Foundation is focused on promoting participation it plays a central role in developing athletes across four major disabilities, visual, physical and hearing impairment and learning difficulties, for elite level competitions such as the Special Olympics, Deaflympics and the Paralympic Games. However, while the Foundation prepares athletes for all four major disability areas 'the main focus has to be around wheelchair tennis and the Paralympics ... Our whole programme and the 
work we do with [the athletes] ... is to maximise their opportunities for Rio' (interview 22.12.14).

Talent identification is seen as a particular challenge not only because young disabled people are 'much less likely to be engaged in physical activity', but also because the organisational 'landscape is quite fragmented and one thing that we thought would be more straightforward than it clearly is, is that process of engagement' (interview 22.12.14). In order to overcome the organisational fragmentation the Foundation has 'set up a significant number of ... disability tennis networks around the country. We equip them, we train them, we look to engage with disabled people locally ... you might say that our focus has been on sorting out the supply side' (Interview 22.12.14). The Foundation also brings young athletes to the annual talent camps organised by the Youth Sport Trust. Key members of the local disability tennis networks are schools although it is recognised that the contribution of schools to talent identification depends on the interests and enthusiasm of individual PE teachers resulting in an uneven distribution of opportunities. A further concern is that wheelchair tennis is not yet in the School Games. With regard to seeking talent transfer opportunities the Foundation was admitted that it was an 'area where we are playing catch-up ....we are not as developed as we could be' (interview 22.12.14). What limited the exploitation of talent transfer was the absence of a confident understanding of the physical skills and other attributes by which potential transferees could be judged.

\section{Boccia}

A further area of weakness identified by the TF interviewee was the lack of integration of elite youth support between Sport England and UK Sport. Arguing that talent identification 'tends to fall between two stools' the Foundation has to use its charitable funds to support athletes who are not yet at the elite level (and therefore not yet eligible to be funded by UK Sport) and do not fit the requirements of the England Talent Pathway (funded by Sport England). A similar assessment was provided by Boccia England who noted the 'challenge of integrating Sport England's and UK Sport's approaches to talent identification' (Boccia England interview 02.12.14). 
Boccia England was formed in 2013; the sport was previously administered by CP (Cerebral Palsy) Sport. The formation of a separate England NGB and one at GB level for Paralympic purposes reflects the growth in popularity of the sport in recent years, especially due to its exposure in the Paralympic Games, and the success of the GB Paralympic team. Although Boccia England is a small organisation (eight staff) it receives sufficient funding from Sport England to support its Talent Pathway. Youth athlete development is the responsibility of the home countries and the interviewee from Boccia England noted that his organisation was under some pressure from GB Boccia Federation to identify talent to compete at the Paralympic level. Talent identification takes place at the county and regional levels. Because there are few boccia clubs schools play an important role in encouraging participation and facilitating talent identification. Children can start playing from the age of 11 although structured talent development does not start until the ages of 16 to 17 . The charity, the Lords Taverners, fund an under-19 inter-schools competition which culminates in a final event at the national level.

In 2014 there were around 60 athletes in the development process (in the development squad, the Lions squad or the England squad). Approximately half the development squad were under 19 years of age. Most development activity takes place in talent camps (roughly six per year) as few athletes have a local coach. The competition structure has recently been reorganised to replace the previous pattern of locally organised 'friendlies' with a more effective hierarchy of competition (e.g. from regional to national competitions). The hierarchy of regional and national competitions provides not only a more effective development opportunity but also an opportunity for talent to be spotted for the GB team.

Among the challenges that the NGB faces is the heavy demand on the services of volunteers with many athletes needing one to one support. A second problem is that the sport recruits athletes with a range of disabilities including cerebral palsy, muscular dystrophy and Duchenne muscular dystrophy, some of which are degenerative conditions which means that for some athletes improvements in technique due to coaching can be undermined by degeneration in muscle function. A third problem is that the location, and to an extent, the number, of talent camps that can be organised is limited by the small number of centres that can accommodate 
disabled athletes. A fourth problem is that despite receiving funding from Sport England and UK Sport Boccia England does not have sufficient funds to buy services from the English Institute of Sport (EIS, England's network of elite development centres) for its young development squad athletes: EIS services can only be funded for athletes in the GB squad.

\section{The role of the British Paralympic Association}

For all three sports discussed above preparation for, and success at, the Paralympic Games features prominently. In the UK Paralympic sport is seen by many organisations not only as important in its own right as part of the most significant international sport event for people with disabilities, but also as important in raising the public and political profile of disability sport in general. The recent increase in funding for athletes who wish to compete in the Deaflympics or the Special Olympics, though modest by comparison to the funding received by Paralympians, is nonetheless seen as a beneficial consequence of the UK's sustained success at the Paralympic Games. It is therefore not surprising that the British Paralympic Association (BPA) plays a major role in the development of young talent. However, as the BPA interviewee noted 'everything that we do in the talent remit is very much led and driven by the sports with us being the critical friend and suggesting things that might work but being guided by their systems' (interview 02.02.15). The interviewee was at pains to point out that talent identification and development was in its infancy in Paralympic sports when compared to Olympic sports: 'the programmes are new and still developing so you're in a place of not having a massive base of successful Paralympic sports to be able to draw on' (interview 02.02.15). One of the distinctive features of Paralympic sports is that people can take up a Paralympic sport at a wide range of ages - some from childhood, but others in adult life following injury. Consequently talent camps tend to include a wide age range. The interviewee referred to a recent swimming talent camp that had athletes as young as 13 years who had a congenital disability training alongside exmilitary personnel with acquired disability but who were of the same 'sport age'. Although the BPA invests in talent camps and supports the 'traditional' talent development model (i.e. high levels of grassroots participation with a hierarchy of development squads) it is also a strong supporter of talent transfer and ensuring a degree of adaptability among young disabled athletes. The support for talent transfer 
is partly a consequence of the regularity with which the International Paralympic Committee changes events and disability classifications thus requiring some degree of flexibility on the part of the athlete.

\section{The role of the Youth Sport Trust}

In many respects a more significant organisation for youth elite disability sport is the Youth Sport Trust (YST), a charitable organisation that has been active in the area of youth/school sport since 1994. The YST's objectives are to: improve the quality of physical education in schools; develop opportunities for those with special educational needs and disabilities; and provide opportunities for young people to excel in sport. The Trust's Sporting Chance programme is focused on 13-18 year olds and aims to improve the quality and quantity of opportunities for disabled children to participate in sport. One element within the Sporting Chance programme is focused on improving the quality of coaching, PE teaching and leadership of those working with young disabled athletes. The connection between Sporting Chance, with its emphasis on inclusion, and elite talent identification and development is through the School Games. As mentioned previously the School Games is a hierarchy of competitions which involves over 18,000 schools and which as an explicit concern to provide competition opportunities at regional and national levels for disabled school children. Local and county level School Games competitions are organised locally and may include a number of disability sports but are not required to do so.

At the regional and national competition levels the YST is working with 12 NGBs to develop inclusive formats of their sports and in the last Games six sports were included for athletes with sensory, learning and physical disabilities and included wheelchair basketball and para-badminton. However, one limitation on the range of sports that can be included in the School Games programme is the size of the talent pool. The Trust has attempted to provide competitions in visually impaired judo and sitting volleyball but the pool of available athletes was too small.

The attraction of the School Games to talented young athletes is easy to illustrate with 59 athletes, both disabled and non-disabled, who had taken part the Games going on the win 89 medals at the 2014 Commonwealth Games. The significance of 
the School Games for elite youth disability sport is even greater with disabled athletes accounting for over $75 \%$ of those athletes who reach the top (usually Olympic or Paralympic) level in their sport. Many of Team GB's Paralympic squad had their first experience of a big sporting event atmosphere at the national School Games. According to a senior YST member 'The Games is seen as a fundamental step in progression in sport amongst young people' (interview 21.11.14). However, while the School Games has been successful in contributing to the development of disabled young athletes the Trust acknowledges that it faces a greater challenge in identifying potential disabled participants and thus potential talent. 'One of our biggest areas of discussion with delivery networks is 'where are the young people?' and I think the advance of getting more young disabled people in to mainstream education makes it more difficult in some ways ... the fact that they're scattered around means that a lot of disabilities are just not seen and the kids are just accepted as part of the school it makes it harder to then identify them' (YST interview 21.11.14). Despite the difficulty in locating young athletes with disabilities in mainstream schools the Trust fulfils an important initial identification function in linking young athletes with local disability sport clubs. However, the Trust also contributes to the talent development of disabled athletes as, in addition to organising the national School Games, the YST also runs an annual talent camp for both disabled and non-disabled young people. In 2014 the talent camp included athletics, tennis and volleyball all of which had disabled athletes involved.

\section{The role of government agencies - Sport England and UK Sport Wheelchair basketball} GBWBA have a very positive view of the role of the Sport England England Talent Pathway programme which is considered to be a useful tool for supporting and assessing progress in athlete development. Even though the funding received from Sport England is modest it contributes to the cost of employing a talent officer. Moreover, if the Association only had access to UK Sport funding it would not be able to support the development squads at the regional level and at the U15 and U19 levels. However, the income from UK Sport can be used to finance the U22 and U25 development squads as the squads are UK-wide rather than focused on 
England or one of the other home countries. UK Sport provides funding over an eight year cycle, but the Association acknowledges that it needs to do more to refine the 'development system' rather than simply fund more athletes. Two concerns with the current funding allocation were mentioned. The first related to the disparity between Olympic and Paralympic funding with the former being funded far more generously. For example Olympic athletes receive Podium level funding if there is a prospect of them winning a medal, of whatever metal, at the Olympic Games whereas Paralympic athletes will receive funding only if they are considered likely to win a gold medal. The second concern is that, as is the case with Olympic sports, the fact that wheelchair basketball is a team sport means that a large squad has to be supported although there is only one medal to be won. The attraction to UK Sport of funding wheelchair basketball has to be set alongside other sports, such as swimming, where there are many disability classifications and consequently many more medals on offer at a lower unit cost.

\section{Disability tennis}

The Tennis Foundation had a similarly broadly positive view of the support that it receives from both UK Sport and Sport England. In endorsing UK Sport's emphasis on medals as the key performance indicator it was commented that 'it focuses us in a very clear way on what we have to do to optimise the chance of medal winning' (interview 22.12.14). However, there was also a recognition that an over-emphasis on elite sport can be off-putting for disabled people and that the Foundation needed to ensure that it had a broad range of opportunities for participation (whether in clubs with a primary sport purpose or in those where sport is only one element in the club's provision) with links to the talent pathway should the participant be interested in pursuing competition at higher levels.

\section{Boccia}

As with GBWBA and the Tennis Foundation funding from Sport England and UK Sport is essential for the elite youth development activity of Boccia England although the NGB does receive some additional funding from charities such as the Lords Taverners. However, in common with many other sports Boccia England works to a 6 to 8 year development cycle, but feels under considerable pressure to produce results within four years - that is in line not only with the Paralympic Games cycle, 
but also in line with the funding review cycle of government. Despite the increase in funding in recent years it was pointed out that at England level athletes still have to fund their own travel due to the lack of resources within the NGB.

\section{Managing athlete welfare}

\section{Wheelchair basketball}

A central concern for GBWBA is the age at which it is advisable for athletes to start training and playing competitively. Apart from the physical and psychological developmental considerations that would apply to any sport wheelchair basketball has the additional concern which relates to the damage that a young athlete can experience from using an unsuitable chair. As a result the normal age at which an athlete is accepted into the national development squad is 14 years although there have been a few exceptions and 13 year olds have been accepted. However, children can play for their club in the junior league from the age of 11 (although they can train from a younger age). Whether a young athlete is accepted or not into the national development squad is left to the judgement of coaches and 'coaches are expected to differentiate and evidence that differentiation' (GBWBA interview 17.11.14). All coaches working with young players are obliged to undertake child protection courses as part of their training.

\section{Disability tennis and Boccia}

Like GBWBA the Tennis Foundation sees the training and development of coaches as central to the protection of the welfare of disabled tennis players. According to the TF interviewee:

'We have a very experienced team of coaches, probably one of the most experienced across any wheelchair or disability sport ... and they have an acute sense of the cultural as well as the elite performance elements. ... We're very conscious about what is required generally to support disabled athletes and we go to a lot of extra effort to do so.... We have a couple of very talented, younger wheelchair athletes, for example, and one of them we are supporting in terms of helping with their schooling and trying to make sure that at the stage of life they are, their welfare and their life opportunities are balanced between optimising education and at the same time providing as much support as we can for their elite sport development. ... So we're conscious that it's not just 
about taking them out of their environment, it's about trying to make them optimise their environment and ... give them the inspiration, but maintain that balance particularly while they're growing up.' (interview 22.12.14)

Similar sentiments were expressed by the interviewee from Boccia England although he emphasised that the extra costs incurred because of the degree of disability of some of the boccia athletes were a constraint on the number of young athletes that could be supported.

\section{The Youth Sport Trust}

The cost of supporting disabled young athletes was also a concern for the Youth Sport Trust. At the 2014 School Games the Trust was hosting 200 disabled athletes (out of a total of 1500) but found that the accommodation block was unsuitable so moved the athletes to hotels. Further evidence of the Trust's commitment to providing opportunities in sport for young disabled people is that $11 \%$ of young volunteers at the 2014 Games were disabled. The involvement of disabled youth volunteers also reflects the attention paid to ensuring the welfare of disabled athletes. To provide a guarantee of a concern for the welfare of young athletes the Trust contracted the Child Protection in Sport Unit (CPSU) and a welfare expert from the International Paralympic Committee to provide advice. A distinctive feature of disability sport which adds significance to the concern with welfare is that 'In Paralympic sports there is a shorter route to the top so if a talent emerges and there is a small talent pool in the classification and sports are judged on medals there is a pressure on them, whether its direct or indirect there is a pressure that they will perceive that they need to win those medals so you've got conflicting things there' (YST interviewee 21.11.14).

\section{The prospects for elite youth disability sport}

For the GBWBA the landmarks in the development of the sport were provision of funding for the elite senior squad in 1997 and for the development squad in 2007 which prompted the Association interviewee to comment that 'the sport has grown immensely. The opportunity to spot talent has grown, the education of the coaches 
[the opportunity] to identify and develop talent has grown' (interview 17.11.14). He also commented that the investment has allowed the identification of talent at younger ages. With regard to the prospects for the sport he commented that the Association needed to broaden its sources of income as it was risky to rely on the continued success of the Paralympic team to trigger UK Sport funding. More positively he pointed to the growth in international competition opportunities for the sport which helped squad development and to the planned development of the female team.

One priority for the Youth Sport Trust is to increase the involvement of young disabled athletes at all levels of the School Games programme. While disabled athletes are reasonably well represented at the national School Games (level 4) involvement and opportunity at the lower levels is more variable. Indeed one concern expressed by the YST interviewee was the low number of young people on the talent pathway. However, there is a significant debate around the question of whether there should be an ambition to have a wider range of disability sports in the School Games - that is at what is often an early stage in the sporting career of young people - or whether preserving a limited number of gateway sports is more beneficial both to the athlete and for Paralympic success. He commented that there while there are still only three significant entry points (gateway sports) for disabled athletes namely swimming, athletics and cycling. It was argued that:

It may be inappropriate to think there should be a School Games competition in every sport ... Policy would say 'why have we not got parity?'. Knowledge would say we don't need parity because we have a good system to develop talent - we win medals at senior level because we do a good job on the three entry sports and diverting young people too early in to other sports might be the wrong thing.(YST interviewee 21.11.14)

However, the challenge still remains of identifying a greater proportion of disabled young people so that the offer of sport involvement can be made. To that end the Trust aims to have at least one Project Ability school (a school with a strong commitment to disability sport) on all level 3 (regional) organising committees. 


\section{Discussion and conclusions}

As mentioned in the introduction to this article analyses of elite sport systems across a wide variety of countries and sports have noted a high degree of convergence. Although the present study is limited to a small number of sports and sport organisations in one country there is evidence to suggest that convergence may well be a feature of disability sport particularly in relation to talent identification and development.

\section{Table 2 about here}

Table 2 summarises the pattern and extent of convergence found acros $\theta$ s the three sports using the framework presented in Table 1. The dimensions which exhibited the clearest evidence of convergence were numbers one, two and three - 'motives', 'agenda and aspiration' and 'contextualising discourse/ideology/values'. The pattern of change in relation to 'implementation' found in all three sports (in terms of investrment in coaching, competition and training camps for example) indicated a high degree of uniformity in motives, aspirations and values. Although there wereas some continuing differences in the sources of funding between mainstream and disability sport there was considerable similarity between the three sports.

Using

Hall's typology as an additional analytical lens it can be argued that all three sports supported by YST and the BPA provided ample evidence of convergence at the first order of change - that is, alterations in the intensity or scale of an existing policy instrument and which correspond broadly to dimensions four and five in Table 2. First, all three sports have experienced a significant increase in funding from UK Sport: boccia from £0.6m for preparation for Beijing in 2008, £2.3m for London 2012 and $£ 3.6 \mathrm{~m}$ for Rio de Janeiro 2016 ; wheelchair basketball, from $£ 3.1 \mathrm{~m}, £ 4.5 \mathrm{~m}$ to $£ 5.3 \mathrm{~m}$ for 2016; and wheelchair tennis $£ 0.8 \mathrm{~m}$, £0.8m to £1.9m for 2016. Increase in funding from UK Sport has generally been matched by similar increases from Sport England part of which supports the England Talent Pathway aimed particularly at the identification and development of young athletes. Second, the ways in which each of 
the sports used its increased resources is broadly similar with the priorities being to increasing the quality of coaching available in the sport and to increasing the opportunities for elite squad development through the organisation of talent camps and centres of excellence. In addition there is also convergence in the attempt to make the identification of talent more systematic and scientific. What is not surprising is the extent to which the elements of an elite disability sport system that are being put in place mirror those that already exist in non-disabled sport.

There is also evidence of second order changes resulting in convergence. Second order changes are those that introduce new policy instruments designed to achieve existing policy objectives (related to dimensions four and five in Table 2). One example of second order change is the extent to which all three sports have constructed, or aspire to construct, patterns of competition that facilitate talent development and progression to national representative level. This policy innovation might be interpreted as an expected outcome of a broader basis of participation, but the evidence suggests that this development reflects a prioritisation of the needs of athletes who aspire to elite sport over those whose aspirations are for recreational or purely social sport participation. A second example of incipient, if not actual, policy change concerns attitudes towards talent transfer. Although the GBWBA saw little potential in pursuing talent transfer due to the technical nature of their sport others were more positive with the Tennis Foundation acknowledging the potential of the process while also acknowledging that they are not yet equipped to exploit the opportunity. A similarly positive perception of talent transfer was expressed by the BPA although its justification was more complex and was based not simply on wanting to maximise Paralympic medals but was also an acknowledgment of the dynamic environment of Paralympic sport and frequency with which disability classifications were amended.

It is in relation to third order changes, those that involve changes in policy goals which relate to the first three dimensions in Table 2, that the most significant evidence of convergence is available. Two inter-linked changes are evident the first of which is the change in the balance of priority between inclusion and participation on the one hand and performance and excellence on the other. In the late 1990s and early part of the present century the emphasis within disability sport organisations 
was on creating opportunities to participate. Competition was at the club or subregional level and was often a series of 'friendlies' rather than part of a league. The last twenty years has seen the emergence of elite success as a much more prominent organisational priority reinforced by, if not initially prompted by, government funding through UK Sport, Sport England and the National Lottery. While it is certainly plausible to argue that the heightened media profile of elite disability sport has greatly helped in the promotion of participation it is possible to argue that participation in seen less as an end in itself but increasingly as a means to achieving a stronger elite squad.

Furthermore, the policy objective of achieving elite success at the international level is heavily skewed in favour of the Paralympic Games with far less attention paid to success in the competitions such as the Deaflympics and the Special Olympics. The prioritisation given to Paralympic success and which is reflected in the substantial funding that has flowed to Paralympic NGBs is not hard to explain. The organisational links between the Olympic Games and the Paralympic Games has greatly enhanced the public, political and commercial profile of the competition. However, it needs to be borne in mind that the events available at the Paralympics cater for the elite performance aspirations of a relatively narrow range of disabilities. Consequently, there is a risk that far from opening up opportunities for talented young disabled athletes to perform at the highest level the over-emphasis on Paralympic sports is in fact narrowing opportunity.

It would be churlish indeed to ignore the benefits for young disabled athletes that have resulted from the increasing prominence of Paralympic sport. The benefits have not only been experienced by those talented young people who are able to enjoy the excitement and satisfaction of competition at the highest level, but also by those seeking to participate at a recreational level. However, as evidence from nondisabled sport suggests it is difficult to maintain parity of esteem between the policy objectives of maximising participation and maximising medals. The evidence from this study suggests that disability sport organisations are also finding the maintenance of such a balance problematic and as such is one of a number of areas which would benefit from further research. 
The paucity of research in the area of elite disability sport in general and in relation to youth TID in particular requires prioritisation of research topics. One of the most pressing questions is how the increasing profile of elite disability sport has affected the development of the sport at the recreational/ participation level. It could be argued that the substantial increase in charitiable and public funding coming into elite youth disability sport should have benefits for all levels of the sport. However, this hypothesis has yet to be tested and it is always wise to be sceptical about models of resource distribution which rely on 'trickle down' assumptions. One potential danger is that the perception of young disabled people becomes distorted whereby they are seen less as the subject of organisational action and more an object or resource for Paralympic competition. Rather than disability sport organisations asking what the sport can do for young people there is the risk that they ask what the young people can do for the sport.

A seond area for research is to compare the elite development systems of disability sports which are not included in the Paralympic programme with those that are included in the Paralympic Games. How those systems differ in terms of funding, organisational support from Sport England and UK Sport and access to the specialist services of the English Institute of Sport are all areas for enquiry. A third area for further research is to examine the degree of convergence between those disability sports that are integrated into a mainstream NGB and those that retain an independent existence. One line of enquiry would be to examine whether those disability sports which are integral to a mainstream NGB have greater or reduced capacity to innovate in relation to youth disability TID.

\section{References}

Baker, J. and Cote, J. (2003) Sport-Specific Practice and the Development 
of Expert Decision-Making in Team Ball Sports, Journal of Applied Sports Psychology, 15, 12-25.

Baker, J., \& Young, B. (2014). 20 years later: deliberate practice and the development of expertise in sport. International Review of Sport and Exercise Psychology, 7(1), 135-157.

Béland, D. (2005) Ideas and social policy: an institutionalist perspective. Social Policy \& Administration, 39(1), 1-18.

Bergsgard, N. A., Houlihan, B., Mangset, P., Nødland, S.I. and Rommetvedt, H. (2007). Sport policy: a comparative analysis of stability and change. Oxford: Butterworth Heinemann.

Brackenridge, C. (2001) Spoilsports: Understanding and preventing sexual exploitation in sport, London: Routledge.

Brackenridge, C., Fasting, K., Kirby, S. and Leahy, T. (2010) Protecting children from violence in sport, Florence: UNICEF.

Campbell, J., \& Oliver, M. (2013). Disability politics: understanding our past, changing our future. London: Routledge.

Cashman, R. and Darcy, S. (2008) Benchmark Games: the Sydney 2000 Paralympic Games, Petersham: Wall Walla Press.

Clumpner, R.A. (1994) ' $21^{\text {st }}$ century success in international competition', in R. Wilcox (ed.) Sport in the global village, Morgantown, WV: Fitness Information Technology Inc., pp. 353-63.

David, P. (2005) Human rights in youth sport: A critical review of children's rights in competitive sport, London: Routledge. 
David, P. (2008) Human rights of young athletes. In B. Houlihan (ed) Sport and Society: A student introduction, London: Sage.

De Bosscher, V., Bingham, J., \& Shibli, S. (2008) The global sporting arms race: An international comparative study on sports policy factors leading to international sporting success. Aachen: Meyer \& Meyer Verlag.

De Bosscher, V., Knop, P. D., \& van Bottenburg, M. (2009a). An analysis of homogeneity and heterogeneity of elite sports systems in six nations. International Journal of Sports Marketing and Sponsorship, 10 (2), 111-131.

De Bosscher, V., De Knop, P., Van Bottenburg, M., Shibli, S., \& Bingham, J. (2009b). Explaining international sporting success: An international comparison of elite sport systems and policies in six countries. Sport Management Review,12(3), 113-136.

Donnelly, P. (1997) Child labour, sport labour: Applying child labour laws to sport, International Review for the Sociology of Sport, 32(4), 389-406.

Finch, N. (2001). Young People with a Disability and Sport 2000: Main Report. Sport England.

Fitzgerald, H. (Ed.). (2009) Disability and youth sport. London: Routledge.

Gold, J. R., \& Gold, M. M. (2007). Access for all: the rise of the Paralympic Games. The Journal of the Royal Society for the Promotion of Health, 127(3), 133-141.

Green, M., \& Houlihan, B. (2005) Elite sport development: Policy learning and political priorities, London: Routledge.

Hall, P.A. (1986) Governing the economy: The politics of state intervention in Britain and France, Cambridge: Polity Press. 
Hall, C. M. (2011) Policy learning and policy failure in sustainable tourism governance: from first-and second-order to third-order change?. Journal of Sustainable Tourism, 19(4-5), 649-671.

Helsen, W. F., Hodges, N. J., Van Winckel, J., \& Starkes, J. L. (2000) The roles of talent, physical precocity and practice in the development of soccer expertise. Journal of Sports Sciences, 18, 727-736.

Houlihan, B., \& Green, M. (Eds.) (2008). Comparative elite sport development. Oxford: Butterworth Heinemann.

Houlihan, B. (2012)Sport policy convergence: a framework for analysis, European Sport Management Quarterly, 12 (2), 111-135.

Howe, P. D. (2008): From Inside the Newsroom Paralympic Media and the Production'of Elite Disability. International Review for the Sociology of Sport, 43(2), 135-150.

Jordan, A., Wurzel, R. K., \& Zito, A. R. (2003): 'New'_instruments of environmental governance: Patterns and pathways of change.

Krippendorf, K. (2013) (3. $3^{\text {rd }}$ edition). Content analysis: An introduction to its methodology, Los Angeles: Sage.

Lascoumes, P., \& Le Gales, P. (2007). Introduction: understanding public policy through its instruments-from the nature of instruments to the sociology of public policy instrumentation. Governance, 20(1), 1-21.

Legg, D., \& Steadward, R. (2011). The Paralympic Games and 60 years of change (1948-2008): unification and restructuring from a disability and medical model to sport-based competition. Sport in Society, 14(9), 1099-1115.

Lewis, J. (2002) Gender and welfare state change. European societies, 4(4), 331357. 
Liu, Y. D. (2009). Sport and social inclusion: Evidence from the performance of public leisure facilities. Social Indicators Research, 90(2), 325-337.

Martens, R. (ed.) (1978) Joy and sadness in children's sport, Champaign, IL.: Human Kinetics.

May, T. (1997), Social research: Issues, methods and process, Buckingham: Open University Press.

Oakley, B. and Green, M. (2001) Still playing the game at arm's length? The selective re-investment in British sport, 1995-2000. Leisure studies, 6 (2), 74-94.

Oliver, M. (1983) Social work with disabled people, Basingstoke: Macmillan.

Oliver, M. (2013) The social model: thirty years on, Disability and Society, 28 (7), 1024-6

Oliver, M. and Barnes, C. (2012) The new politics of disablement, Basingstoke: Palgrave Macmillan

Origins, H. B. (2000). Government, interest groups and policy change. Political studies, 48, 1006-1025.

Prince, M. J. (2009). Absent citizens: Disability politics and policy in Canada.

Toronto: University of Toronto Press.

Purdue, D. E. J., \& Howe, P. D. (2012). See the sport, not the disability: exploring the Paralympic paradox. Qualitative Research in Sport, Exercise and Health, 4(2), 189205.

Radaelli, C. M. (2003). The Europeanization of public policy. The politics of Europeanization, 27-56. 
Rose, R. (2005) Learning from comparative public policy: A practical guide, London: Routledge.

Ryan, J. (1995) Little girls in pretty boxes: The making and breaking of elite gymnasts and figure skaters, New York: Doubleday.

Silva, C. F., \& Howe, P. D. (2012). The (in) validity of supercrip representation of Paralympian athletes. Journal of Sport \& Social Issues, 36(2), 174-194.

Simon, H. A., \& Chase, W. G. (1973). Skill in chess. American Scientist, 61, 394403.

Siperstein, G. N., Glick, G. C., \& Parker, R. C. (2009). Social inclusion of children with intellectual disabilities in a recreational setting. Journal Information, 47(2).

Skille, E. and Houlihan, B. (2014) The contemporary context of elite youth sport: the role of national sport organisations in the UK and Norway. In D.V. Hanstad, M.M. Parent and B. Houlihan (eds.) The Youth Olympic Games, London: Routledge.

Smith, B. (2013). Disability, sport and men's narratives of health: A qualitative study. Health psychology, 32(1), 110.

Sport and Recreation Alliance (2013) Sports club survey 2013, London SRA. Starkes, J. L., Deakin, J. M., Allard, F., Hodges, N. J., and Hayes, A. (1996). Deliberate practice in sports: What is it anyway? In K. A. Ericsson (Ed.), The road to excellence: The acquisition of expert performance in the arts, sciences, sports and games (pp. 81-106). Mahwah, NJ: Erlbaum.

Strauss, A.L. \& Corbin, J. (1990) Basics of qualitative research: Grounded theory procedures and techniques, Newbury Park, Cal.: Sage. 
Thomas, N. (2008) Sport and disability. In B. Houlihan (ed) Sport and Society: A student introduction $\left(2^{\text {nd }}\right.$ edn.), London: Sage.

Thomas, N. \& Smith, A. (2008). Disability, sport and society: An introduction. London: Routledge.

Tofler, I.R, Stryer, B.K., Micheli, L.J. and Herman, L.R (1996) Physical and emotional problems of elite gymnasts, New England Journal of Medicine, 335 (4), 281-83.

Vaughn Switzer, J. (2003) Disabled Rights: American Policy and the Fight for Equality, Washington, D.C.: Georgetown University Press.

Veerman, P.E. (1992) The rights of the child and the changing image of childhood, Dordrecht: Martinus Nijhoff.

Young B. W., \& Salmela, J. H. (2002). Perceptions of training and deliberate practice of middle distance runners. International Journal of Sport Psychology. 33 (2), 167181. 